\title{
Dopamine, oxytocin, and vasopressin receptor binding in the medial prefrontal cortex of monogamous and promiscuous voles
}

\author{
Michael D. Smeltzer, J. Thomas Curtis, Brandon J. Aragona, Zuoxin Wang* \\ Department of Psychology and Program in Neuroscience, Florida State University, Tallahassee, FL 32306-1270, USA
}

Received 17 July 2005; received in revised form 24 September 2005; accepted 7 October 2005

\begin{abstract}
Comparisons between monogamous and promiscuous vole species have proven useful in examining neurobiological mechanisms underlying social attachment. Reward processing is important for social attachment, and the medial prefrontal cortex (mPFC) exerts a direct influence on reward pathways. Dopamine (DA), oxytocin (OT), and arginine vasopressin (AVP) all have been implicated in the regulation of social attachment in monogamous voles. Therefore, we used radiolabeled ligands to examine dopamine $\mathrm{D}_{1}$ - and $\mathrm{D}_{2}$-like, OT, and AVP $\mathrm{V}_{1 \mathrm{a}}$ receptor binding densities in the $\mathrm{mPFC}$ of monogamous and promiscuous voles. Species differences were found; monogamous voles had higher densities of $\mathrm{D}_{2}$-like and OT receptor binding and lower densities of $\mathrm{D}_{1}$-like and $\mathrm{V}_{1 \mathrm{a}}$ receptor binding than did promiscuous voles. Sex differences also were found; females had higher densities of OT receptor binding but lower densities of $\mathrm{V}_{1 \mathrm{a}}$ receptor binding than did males in both species. Further, the laminar distribution of receptor binding indicates the possibility of an interaction between DA and OT systems in the mPFC in the regulation of social attachment. Differences in $\mathrm{D}_{1}$ - and $\mathrm{D}_{2}$-like receptor binding between species are discussed in terms of how they might modulate cortical activity and subsequent DA release in the nucleus accumbens (NAcc).
\end{abstract}

(C) 2005 Elsevier Ireland Ltd. All rights reserved.

Keywords: Dopamine; Neuropeptides; Receptors; mPFC; Monogamy

Social attachments are a vital part of healthy human behavior and an inability to form such attachments is regarded as a symptom of mental disorders such as schizophrenia and autism. Studying the mechanisms underlying social attachment requires a model animal that displays behaviors similar to what is seen in human social attachment. Since traditional laboratory animals such as rats and mice do not display the requisite behaviors, prairie voles (Microtus ochrogaster) have become an important model for the study of the neurobiology of social attachment $[5,17,38,46]$. Prairie voles are monogamous and form life-long breeding pairs in which both sexes occupy a common nest, guard against intruders, and retrieve and care for pups [10]. Other vole species, such as montane (Microtus montanus) and meadow voles (Microtus pennsylvanicus), display different life strategies and social behaviors. These species are promiscuous, display low levels of social affiliation, do not selectively mate with one partner, and only the female cares for pups $[9,18,25]$. Thus, voles serve as an excellent comparative model, and com-

\footnotetext{
* Corresponding author. Tel.: +1 850644 5057; fax: +1 8506447739.

E-mail address: zwang@ @psy.fsu.edu (Z. Wang).
}

parisons between monogamous and promiscuous vole species have yielded significant insights into the neurobiology of social attachment $[8,15,16,20,41,42]$.

Central dopamine (DA) is important for the formation of attachments between adult male and female prairie voles (pair bonding) $[1,12,39]$. Dopaminergic cells in the ventral tegmental area (VTA) project both to the nucleus accumbens (NAcc) and the medial prefrontal cortex (mPFC) [22,32]. In turn, the mPFC sends glutamatergic projections back to the VTA and to the NAcc [3,4]. Dopamine in the mPFC modulates the activity of glutamatergic projections to NAcc to regulate local DA release $[19,34]$. Since DA release in the NAcc is important for pair bonding in prairie voles $[1,12,24]$, DA receptors in the mPFC may play a role in this process. Therefore, the first part of the present study was designed to compare the distributions of $\mathrm{D}_{1^{-}}$and $\mathrm{D}_{2}$-like DA receptors in the mPFC of monogamous and promiscuous vole species.

The neuropeptides oxytocin (OT) and arginine vasopressin (AVP) also are involved in pair bonding $[7,13,23,43,44]$. The central distributions of OT and AVP $V_{1 a}$ receptors differ between monogamous and promiscuous voles $[15,16,42]$. Further, the impact of these neuropeptide systems on pair bonding differs 
between sexes in monogamous voles: females are more sensitive to OT whereas males are more sensitive to AVP $[7,13,44]$. Importantly, microinjection of an OT receptor antagonist into the $\mathrm{mPFC}$ alters pair bond formation in female prairie voles [45]. Although untested in the mPFC, AVP manipulations in the lateral septum and ventral pallidum are known to alter pair bonding in male voles [20,21,23]. Therefore, in the second part of the present study, we assessed OT and AVP $\mathrm{V}_{1 \mathrm{a}}$ receptor distributions in the mPFC of monogamous and promiscuous voles. In both the DA and neuropeptide experiments, males and females were included to examine potential sex differences in receptor binding. We hypothesized that DA/OT/AVP receptor distributions in the mPFC differ between monogamous and promiscuous voles, and that such differences may contribute to species-specific social attachment behavior.

Subjects were sexually naive adult male and female prairie, meadow, and montane voles from captive breeding colonies. All animals were weaned at 21 days of age, and were housed in same-sex sibling groups (2-3/cage) in plastic cages $(20 \mathrm{~cm} \times 50 \mathrm{~cm} \times 40 \mathrm{~cm})$ under a $14 \mathrm{~h}$ light $/ 10 \mathrm{~h}$ dark cycle with lights on at 07:00 h. Temperature was maintained at about $20^{\circ} \mathrm{C}$. Food and water were provided ad libitum. All experimental procedures were in accordance with National Institutes of Health guidelines, and were approved by the Florida State University Animal Care and Use Committee.

The first part of this study was designed to examine DA receptor binding in the $\mathrm{mPFC}$ of monogamous and promiscuous voles. At about 3 months of age, sexually naive prairie and meadow vole subjects were anesthetized with sodium pentobarbital ( $1 \mathrm{mg} / 10 \mathrm{~g}$ body weight) and decapitated. Brains were removed and frozen on dry ice, then cut into $15 \mu \mathrm{m}$ coronal sections on a cryostat and thaw-mounted onto Superfrost/Plus slides (Fisher). Sections were stored at $-80^{\circ} \mathrm{C}$ until processed for DA receptor autoradiographic binding.

The second part of this study was to examine OT and AVP $V_{1 a}$ receptor binding in the $\mathrm{mPFC}$ of monogamous and promiscuous voles. These data were obtained from autoradiographs processed in previous studies [41,42]. Those experiments focused on the ontogenetic patterns of OT and AVP $\mathrm{V}_{1 \mathrm{a}}$ receptor binding in selected brain regions in prairie and montane voles, and detailed analyses of the mPFC were not performed.

For DA receptor binding, adjacent brain sections at $90 \mu \mathrm{m}$ intervals were rinsed in $50 \mathrm{mM}$ Tris- $\mathrm{HCl}$ ( $\mathrm{pH} 7.4$ ) $2 \mathrm{~min} \times 10 \mathrm{~min}$ and then incubated in the same buffer with $120 \mathrm{mM} \mathrm{NaCl}, 5 \mathrm{mM} \mathrm{KCl}, 2 \mathrm{mM} \mathrm{CaCl} 2,1 \mathrm{mM} \mathrm{MgCl}_{2}$ and $50 \mathrm{pM}{ }^{125} \mathrm{I}-\mathrm{SCH} 23982$ (for $\mathrm{D}_{1}$-like receptors) or ${ }^{125} \mathrm{I}-2^{\prime}$ iodospiperone (for $\mathrm{D}_{2}$-like receptors) (Perkin-Elmer, MA). Fifty nM ketanserin (RBI, MA) was added to prevent binding to 5$\mathrm{HT}_{2}$ receptors. After $45 \mathrm{~min}\left(\mathrm{D}_{1}\right)$ or $90 \mathrm{~min}\left(\mathrm{D}_{2}\right)$ incubations at room temperature, sections were rinsed in fresh ice-cold buffer containing $0.1 \%$ paraformaldyhyde and then twice in ice-cold buffer for $5 \mathrm{~min}$, followed by immersion in buffer for $60 \mathrm{~min}$ with gentle stirring. Finally, sections were rinsed in ice-cold $\mathrm{ddH}_{2} \mathrm{O}$ and dried under a stream of cool air. Nonspecific binding was defined by pretreating adjacent sections with SCH23390 or eticlopride prior to incubation in the buffer containing ${ }^{125} \mathrm{I}-\mathrm{SCH} 23982$ or ${ }^{125} \mathrm{I}-2^{\prime}$-iodospiperone, respectively.
Slides were exposed to BioMax MR film for approximately $4 \mathrm{~h}$.

Detailed procedures for OT and AVP $\mathrm{V}_{1 \mathrm{a}}$ receptor binding were described previously [41,42]. OT or AVP $\mathrm{V}_{1 \mathrm{a}}$ receptor binding was processed by using $50 \mathrm{pM}^{125} \mathrm{I}$-OTA or ${ }^{125} \mathrm{I}$-linearAVP (Perkin-Elmer, MA), respectively. Non-specific binding was defined by pretreating adjacent sections with the selective OT antagonist, [Thr ${ }^{4} \mathrm{Gly}^{7}$ ]OT $(1 \mu \mathrm{M})$, followed by incubation in the buffer containing ${ }^{125} \mathrm{I}$-OTA, or with the $\mathrm{V}_{1 \mathrm{a}}$ ligand, $\mathrm{d}\left(\mathrm{CH}_{2}\right)_{5}[\mathrm{Tyr}(\mathrm{Me})]$ AVP $(1 \mu \mathrm{M})$, followed by incubation with ${ }^{125}$ I-linear-AVP [41,42].

The autoradiographs were analyzed for the densities of $\mathrm{D}_{1}$ and $\mathrm{D}_{2}$-like DA receptor and OT and AVP $\mathrm{V}_{1 \mathrm{a}}$ receptor binding in the mPFC using the NIH IMAGE program. Sections were anatomically matched between subjects, and individual means for each subject were obtained by measuring grain density bilaterally in four sections from the mPFC. The background density was subtracted from the measurement of each section. Data for each receptor type were analyzed by a two-way analysis of variance (ANOVA, species-by-sex), followed by a Student-Newman-Keuls (SNK) posthoc test when significant main effects were found.

Specific binding in $\mathrm{mPFC}$ was found for all four receptor types. $\mathrm{D}_{1}$-like receptors appeared to be concentrated in deep layers of the cortex (Fig. 1A and B), while $\mathrm{D}_{2}$-like receptors were more evenly distributed throughout all layers of the cortex (Fig. 1D and E). While anatomical distribution patterns of each type of DA receptor binding appeared similar in both species, the densities of DA receptor binding in $\mathrm{mPFC}$ differed between species. Prairie voles had lower densities of $\mathrm{D}_{1}$-like receptor binding $\left(F_{1,19}=10.9, p<0.01\right.$; Fig. $\left.1 C\right)$ and higher densities of $\mathrm{D}_{2}$-like receptor binding $\left(F_{1,18}=13.9, p<0.01\right.$; Fig. $\left.1 \mathrm{~F}\right)$ than did meadow voles. No main sex differences were detected for either type of DA receptor in the mPFC. However, a speciesby-sex interaction was found for $\mathrm{D}_{1}$-like receptor binding, in which male prairie voles had a lower density of $\mathrm{D}_{1}$-like receptor binding than did all other groups $\left(F_{1,19}=7.9, p<0.01\right.$; Fig. $\left.1 \mathrm{C}\right)$. A species-by-sex interaction was not found for the density of $\mathrm{D}_{2}$-like receptor binding in $\mathrm{mPFC}$.

OT receptor binding appeared to be highest in the deep layers of $\mathrm{mPFC}$ in both vole species (Fig. 2A and B). Prairie voles had higher densities of OT receptor binding than did montane voles $\left(F_{1,16}=29.5, p<0.001 ; \mathrm{Fig} .2 \mathrm{C}\right)$. A sex difference was also found; females had higher densities of OT receptor binding than did males $\left(F_{1,16}=40.4, p<0.001\right.$; Fig. $\left.2 \mathrm{C}\right)$. Further, AVP $\mathrm{V}_{1 \mathrm{a}}$ receptor binding appeared to be mainly concentrated in superficial layers of mPFC in both species (Fig. 2D and E). Densities of $\mathrm{V}_{1 \mathrm{a}}$ receptor binding in mPFC were higher in montane than in prairie voles $\left(F_{1,16}=38.6, p<0.001\right)$, and were higher in males than in females $\left(F_{1,16}=14.2, p<0.01\right.$; Fig. $\left.2 F\right)$. No species-bysex interaction was found for either OT or $A V P V_{1 a}$ receptor binding in the mPFC.

The present study was conducted to compare the dopamine $\mathrm{D}_{1}$ - and $\mathrm{D}_{2}$-like, OT, and $\mathrm{AVP} \mathrm{V}_{1 \mathrm{a}}$ receptor binding in the mPFC between males and females of vole species with different life strategies and social behaviors. We found differences in the regional densities and distribution patterns of each type of 


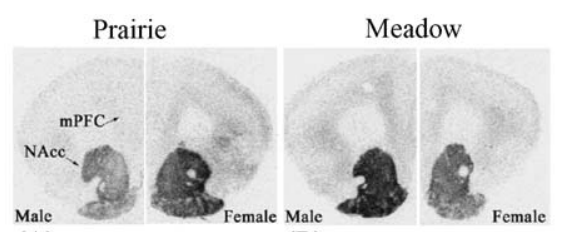

(B)

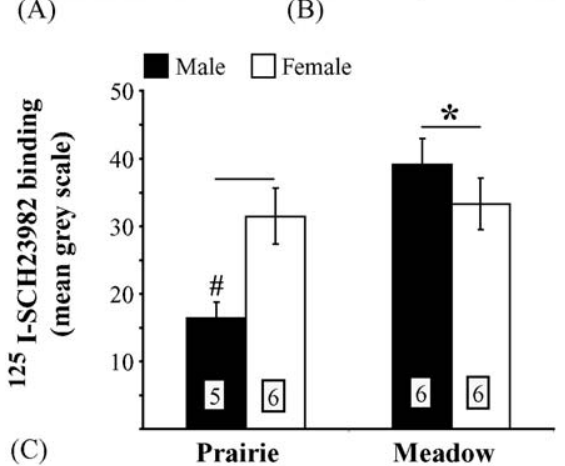

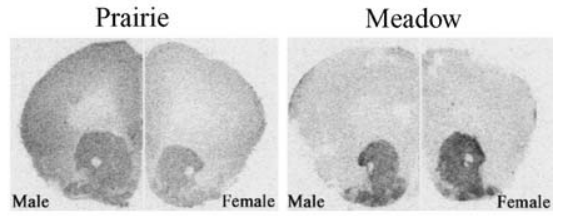

(D)

(E)

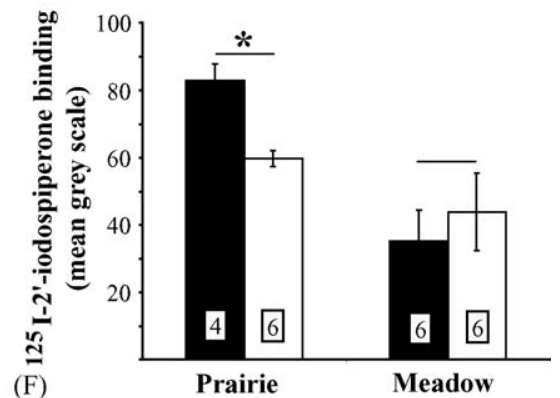

Fig. 1. Species and sex differences in $\mathrm{D}_{1}-(\mathrm{A}-\mathrm{C})$ and $\mathrm{D}_{2}$-like (D-F) dopamine receptor binding in the mPFC. Each photoimage is composed with male on the left and female on the right. Prairie voles had less $\mathrm{D}_{1}$-like and more $\mathrm{D}_{2}$-like receptor binding than did meadow voles. Further, male prairie voles had the lowest density of $\mathrm{D}_{1}$-like receptor binding in $\mathrm{mPFC}$ than did any other groups. Data are presented as mean \pm S.E.M. $\left({ }^{*}\right)$ species differences; (\#) sex difference within each species; mPFC: medial prefrontal cortex; NAcc: nucleus accumbens. Group sizes are shown within each bar.

receptors in the mPFC between monogamous and promiscuous voles. In addition, sex differences also were found, particularly for OT and AVP receptor binding in mPFC. It should be noted that social behaviors were not tested on the animals used in the present study because extensive data have amply demonstrated that these species show different social behaviors, including mating-induced pair bonding, selective aggression, and parental care $[14,25,26,38,44,46]$, which served as a foundation for formation of our hypothesis. Furthermore, displaying social behaviors may cause changes in receptor densities of the DA/OT/AVP systems that are involved in the regulation of those social behaviors. As such we chose not to pre-screen animals for specific behavioral characteristics and instead relied on an extensive literature showing that the majority of individuals in each species display species-specific behaviors. We feel that the inclusion of randomly chosen sexually naive animals provides a better indication of within-species variability, and, as such, makes the analyses more conservative.

One drawback of the present study is the use of two promiscuous species; meadow voles were used in the DA receptor binding experiment whereas montane voles were used in the neuropeptide receptor binding experiment that was previously conducted. This discrepancy was due to the fact that we no longer have a montane vole colony for the DA receptor binding experiment and that we did not feel justified to sacrifice another 20 or more animals for the neuropeptide receptor binding experiment as the

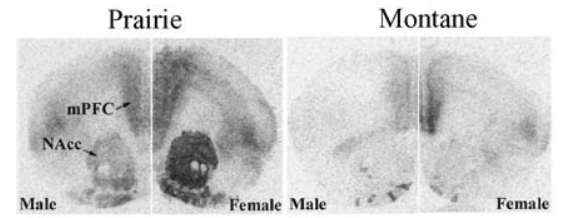

(A)

(B)

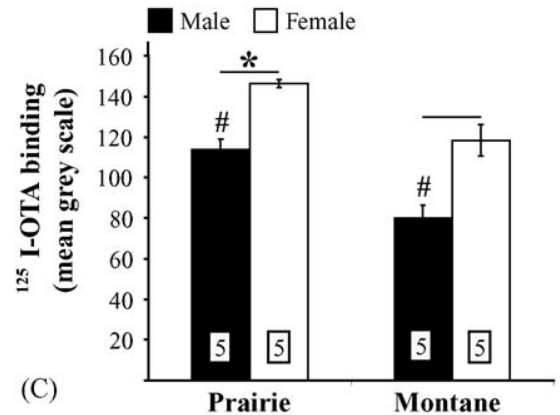

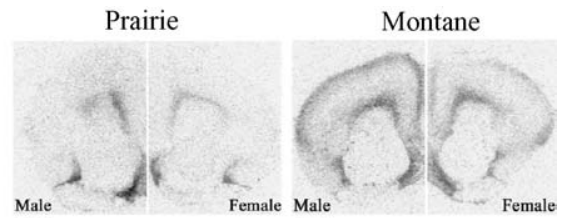

(E)

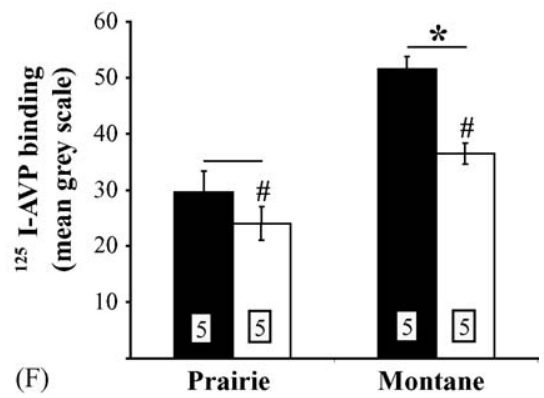

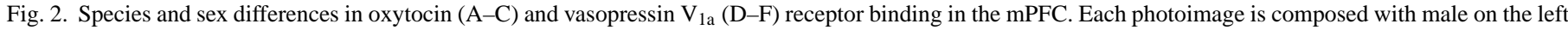

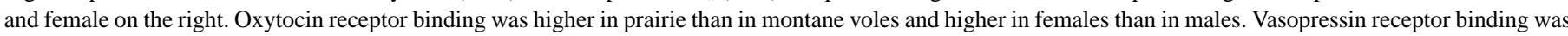

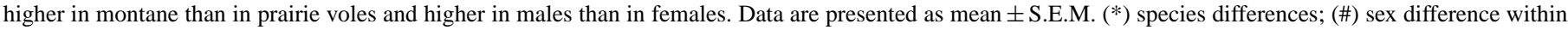
each species; mPFC: medial prefrontal cortex; NAcc: nucleus accumbens. Group sizes are shown within each bar. 
autoradiographs were available from the previous studies. Both montane and meadow voles are promiscuous and display similar social behaviors $[6,38,40]$, and importantly, the two show similar distribution patterns of the OT and AVP $\mathrm{V}_{1 \mathrm{a}}$ receptor binding that differ from those in monogamous voles $[15,16]$. However, as we cannot exclude a possibility that differences in the DA/OT/AVP receptor binding in the $\mathrm{mPFC}$ are species-specific, caution will need to be taken for data interpretation.

In rats, $\mathrm{D}_{1}$ - and $\mathrm{D}_{2}$-like $\mathrm{DA}$ receptors are mostly located in cortical layers V and VI [30,36], and these layers contain the most DAergic terminals [29,35]. We found similar laminar distributions of $\mathrm{D}_{1}$-like receptors in both species, which were noticeably concentrated in deep layers of the cortex, while $\mathrm{D}_{2}$ like receptors seemed to be more evenly distributed throughout all layers in both species.

Monogamous voles had lower $\mathrm{D}_{1}$ - and higher $\mathrm{D}_{2}$-like receptor binding in the mPFC than did promiscuous voles. This species difference may reflect an adaptation in the mPFC associated with a monogamous life strategy. The cell population in the mPFC consists of mostly glutamatergic excitatory projection neurons and GABAergic inhibitory interneurons, typically identified as pyramidal or nonpyramidal neurons, respectively [27]. In the rat, $D_{1}$-like receptors are found almost exclusively on nonpyramidal neurons, while $\mathrm{D}_{2}$-like receptors are found in both small pyramidal and large nonpyramidal neurons, and both subtypes may also be colocalized on nonpyramidal neurons [37]. Because $D_{1}$-like receptors are coupled to stimulatory $G_{-}$ proteins, activation of these receptors on GABAergic interneurons ultimately would result in inhibition of excitatory efferents. Activation of $\mathrm{D}_{2}$-like receptors, which are coupled to inhibitory G-proteins, could disinhibit excitatory efferents if located on GABAergic interneurons, or directly inhibit efferents if located on pyramidal neurons. Stimulation of DA receptors in the $\mathrm{mPFC}$ of rats after VTA stimulation or by local application of DA typically results in inhibition of mPFC neurons [19,28,30].

Taking into consideration that pair bond formation in prairie voles depends upon DA release in the NAcc $[1,12,24]$ and that accumbal DA release induced by $\mathrm{mPFC}$ stimulation depends upon activation of glutamate receptors in the VTA and NAcc $[33,34]$, it would seem that inhibition of $\mathrm{mPFC}$ efferent neurons would be unfavorable for pair bond formation. Therefore, presence of fewer $\mathrm{D}_{1}$-like and more $\mathrm{D}_{2}$-like receptors in the prairie vole's mPFC could reflect a modification of receptor compliments on GABAergic interneurons. An increase in the number of $\mathrm{D}_{2}$-like receptors on these neurons would increase the likelihood that they would be inhibited in response to DA release, and a decrease in $\mathrm{D}_{1}$-like receptors would decrease the likelihood that they would be excited by DA release. Reducing the excitability of these neurons would increase activity in $\mathrm{mPFC}$ efferents. Another possibility is that fewer $\mathrm{D}_{1}$-like receptors on GABAergic interneurons result in less activation by accumulated extrasynaptic levels of DA. As most cortical $\mathrm{D}_{1}$-like receptors are located extrasynaptically [31], firing of DAergic cells in the VTA in response to a novel mate could produce an environment in which GABAergic interneurons are more excitable, thus reducing the activity of pyramidal outputs. Lowered excitability of these interneurons in such a situation would be advantageous to an animal that requires glutamatergic input from the mPFC during pair bond formation. Estrogen's ability to increase accumbal DA release [2], however, could negate the need for fewer $\mathrm{D}_{1}$-type receptors in females, and could explain why female prairie voles do not share the low density of $\mathrm{D}_{1}$-like receptors with male prairie voles. A complete understanding of the species- and sex-differences in DA receptors will require further study of the cellular localization of DA receptors in the $\mathrm{mPFC}$, as well as of the effects of DA receptor subtype specific pharmacological manipulations on social attachment in prairie voles.

There were striking inverse distributions of OT and $\mathrm{V}_{1 \mathrm{a}}$ receptors, with the former found primarily in deep layers and the latter in superficial layers of cortex without much overlap between the two. The higher density of OT receptor binding in the $\mathrm{mPFC}$ in monogamous voles compared to that in promiscuous voles is consistent with findings in a previous study [15]. An interesting finding in the current study is that female voles had higher densities of OT receptor binding in $\mathrm{MPFC}$ than did male voles. This finding correlates well with data from past studies showing that female voles are more sensitive to OT effects than are males [13]. Although yet to be determined in voles, sex differences in OT receptor binding likely reflect the influence of sex steroids on the expression of these receptors [11]. While the mechanism through which OT affects neurons in the $\mathrm{mPFC}$ remains unknown, blockade of OT receptors in the mPFC indeed blocked female prairie voles' pair bonding behavior [45]. Therefore, anatomical and pharmacological data together suggest that OT in the mPFC may play a role in social attachment.

While the higher density of $\mathrm{V}_{1 \mathrm{a}}$ receptor binding in the $\mathrm{mPFC}$ of promiscuous voles is a novel finding, it is consistent with the species-specific densities of this receptor in many other brain areas of voles $[16,41,42]$. Furthermore, the presence of more $\mathrm{V}_{1 \mathrm{a}}$ receptors in males than in females would be consistent with past findings indicating that males are more sensitive to AVP than are females $[44,47]$. To date, no pharmacological manipulations of $\mathrm{V}_{1 \mathrm{a}}$ receptors in the $\mathrm{mPFC}$ of voles have been carried out, however, due to the relative low density of these receptors in the $\mathrm{mPFC}$ of prairie voles and their absence in the layers of the cortex that receive DAergic input, it is possible that the AVP system in the mPFC plays little, if any, role in social attachment.

Our current study has shown that $\mathrm{D}_{1}$-like DA and OT receptors seem to be most concentrated in deep layers of the cortex in voles. Although the types of neurons that express DA and/or OT receptors are still unknown, these two receptor systems may interact in the regulation of social attachment. An earlier study manipulating OT and DA receptors in another part of the mesocorticolimbic circuit, the NAcc, has shown that OT or a $\mathrm{D}_{2}$-like receptor agonist injected into the NAcc induces pair bonding in female prairie voles. Furthermore, pair bonding induced either by mating or by activation of OT or DA receptors can be abolished by administration of either an OT or a $\mathrm{D}_{2}$-like receptor antagonist [24]. These data suggest the necessity of concurrent involvement of both OT and DA systems in the NAcc during pair bonding in voles. However, similar pharmacological manipulations of these receptors in the mPFC need to be conducted to 
confirm an interaction between DA and OT in the regulation of social attachment.

\section{Acknowledgements}

This work was supported by National Institutes of Health grants MH58616 and DA19627 to ZW, HD40722 to JTC, and NIH Joint Neuroscience program training grant (NS07437).

\section{References}

[1] B.J. Aragona, Y. Liu, J.T. Curtis, F.K. Stephan, Z.X. Wang, A critical role for nucleus accumbens dopamine in partner-preference formation in male prairie voles, J. Neurosci. 23 (2003) 3483-3490.

[2] J.B. Becker, Gender differences in dopaminergic function in striatum and nucleus accumbens, Pharmacol. Biochem. Behav. 64 (1999) 803-812.

[3] D.B. Carr, P. O'Donnell, J.P. Card, S.R. Sesack, Dopamine terminals in the rat prefrontal cortex synapse on pyramidal cells that project to the nucleus accumbens, J. Neurosci. 19 (1999) 11049-11060.

[4] D.B. Carr, S.R. Sesack, Projections from the rat prefrontal cortex to the ventral tegmental area: target specificity in the synaptic associations with mesoaccumbens and mesocortical neurons, J. Neurosci. 20 (2000) 3864-3873.

[5] C.S. Carter, A.C. DeVries, L.L. Getz, Physiological substrates of mammalian monogamy: the prairie vole model, Neurosci. Biobehav. Rev. 19 (1995) 303-314.

[6] C.S. Carter, L.L. Getz, Monogamy and the prairie vole, Sci. Am. 268 (1993) 100-106.

[7] M.M. Cho, A.C. DeVries, J.R. Williams, C.S. Carter, The effects of oxytocin and vasopressin on partner preferences in male and female prairie voles (Microtus ochrogaster), Behav. Neurosci. 113 (1999) 1071-1079.

[8] J.T. Curtis, J.R. Stowe, Z.X. Wang, Differential effects of intraspecific interactions on the striatal dopamine system in social and non-social voles, Neuroscience 118 (2003) 1165-1173.

[9] D.A. Dewsbury, The comparative psychology of monogamy, Nebr. Symp. Motiv. 35 (1987) 1-50.

[10] L.L. Getz, C.S. Carter, Prairie-vole partnerships, Am. Sci. 84 (1996) $56-62$.

[11] G. Gimpl, F. Fahrenholz, The oxytocin receptor system: structure, function, and regulation, Physiol. Rev. 81 (2001) 629-683.

[12] B. Gingrich, Y. Lui, C. Cascio, Z. Wang, T.R. Insel, Dopamine D2 receptors in the nucleus accumbens are important for social attachment in female prairie voles (Microtus ochrogaster), Behav. Neurosci. 114 (2000) 173-183.

[13] T.R. Insel, T.J. Hulihan, A gender-specific mechanism for pair bonding: oxytocin and partner preference formation in monogamous voles, Behav. Neurosci. 109 (1995) 782-789.

[14] T.R. Insel, S. Preston, J.T. Winslow, Mating in the monogamous male: behavioral consequences, Physiol. Behav. 57 (1995) 615-627.

[15] T.R. Insel, L.E. Shapiro, Oxytocin receptor distribution reflects social organization in monogamous and polygamous voles, Proc. Natl. Acad. Sci. U.S.A. 89 (1992) 5981-5985.

[16] T.R. Insel, Z.X. Wang, C.F. Ferris, Patterns of brain vasopressin receptor distribution associated with social organization in microtine rodents, J. Neurosci. 14 (1994) 5381-5392.

[17] T.R. Insel, L.J. Young, The neurobiology of attachment, Nat. Rev. Neurosci. 2 (2001) 129-136.

[18] F.J. Jannett, Nesting Patterns of Adult Voles, Microtus montanus, in field populations, J. Mamm. 63 (1982) 495-498.

[19] A. Lavin, L. Nogueira, C.C. Lapish, R.M. Wightman, P.E. Phillips, J.K. Seamans, Mesocortical dopamine neurons operate in distinct temporal domains using multimodal signaling, J. Neurosci. 25 (2005) 5013-5023.

[20] M.M. Lim, Z.X. Wang, D.E. Olazabal, X. Ren, E.F. Terwilliger, L.J. Young, Enhanced partner preference in a promiscuous species by manipulating the expression of a single gene, Nature 429 (2004) 754-757.
[21] M.M. Lim, L.J. Young, Vasopressin-dependent neural circuits underlying pair bond formation in the monogamous prairie vole, Neuroscience 125 (2004) 35-45.

[22] O. Lindvall, A. Bjorklund, R.Y. Moore, U. Stenevi, Mesencephalic dopamine neurons projecting to neocortex, Brain Res. 81 (1974) 325-331.

[23] Y. Liu, J.T. Curtis, Z.X. Wang, Vasopressin in the lateral septum regulates pair bond formation in male prairie voles (Microtus ochrogaster), Behav. Neurosci. 115 (2001) 910-919.

[24] Y. Liu, Z.X. Wang, Nucleus accumbens oxytocin and dopamine interact to regulate pair bond formation in female prairie voles, Neuroscience 121 (2003) 537-544.

[25] B. McGuire, M. Novak, A comparison of maternal-behavior in the meadow vole (Microtus pennsylvanicus), prairie vole (Microtus ochrogaster) and pine vole (Microtus pinetorum), Anim. Behav. 32 (1984) $1132-1141$.

[26] D. Oliveras, M. Novak, A comparison of paternal behaviour in the meadow vole Microtus pennsylvanicus, the pine vole M. pinetorum and the prairie vole M. ochrogaster, Anim. Behav. 34 (1986) 519526.

[27] J.G. Parnavelas, A. Dinopoulos, S.W. Davies, The central visual pathways, in: A. Bjorklund, T. Hokfelt, L.W. Swanson (Eds.), Handbook of Chemical Neuroanatomy: Integrated Systems of the CNS. Part II, vol. 7, Elsevier, Amsterdam, 1989, pp. 1-164.

[28] S. Pirot, R. Godbout, J. Mantz, J.P. Tassin, J. Glowinski, A.M. Thierry, Inhibitory effects of ventral tegmental area stimulation on the activity of prefrontal cortical neurons: evidence for the involvement of both dopaminergic and GABAergic components, Neuroscience 49 (1992) $857-865$.

[29] P. Seguela, K.C. Watkins, L. Descarries, Ultrastructural features of dopamine axon terminals in the anteromedial and the suprarhinal cortex of adult rat, Brain Res. 442 (1988) 11-22.

[30] S.R. Sesack, B.S. Bunney, Pharmacological characterization of the receptor mediating electrophysiological responses to dopamine in the rat medial prefrontal cortex: a microiontophoretic study, J. Pharmacol. Exp. Ther. 248 (1989) 1323-1333.

[31] J.F. Smiley, A.I. Levey, B.J. Ciliax, P.S. Goldman-Rakic, D1 dopamine receptor immunoreactivity in human and monkey cerebral cortex: predominant and extrasynaptic localization in dendritic spines, Proc. Natl. Acad. Sci. U.S.A. 91 (1994) 5720-5724.

[32] L.W. Swanson, The projections of the ventral tegmental area and adjacent regions: a combined fluorescent retrograde tracer and immunofluorescence study in the rat, Brain Res. Bull 9 (1982) 321-353.

[33] M.T. Taber, S. Das, H.C. Fibiger, Cortical regulation of subcortical dopamine release: mediation via the ventral tegmental area, J. Neurochem. 65 (1995) 1407-1410.

[34] M.T. Taber, H.C. Fibiger, Electrical stimulation of the prefrontal cortex increases dopamine release in the nucleus accumbens of the rat: modulation by metabotropic glutamate receptors, J. Neurosci. 15 (1995) 3896-3904.

[35] C.G. Van Eden, E.M. Hoorneman, R.M. Buijs, M.A. Matthijssen, M Geffard, H.B. Uylings, Immunocytochemical localization of dopamine in the prefrontal cortex of the rat at the light and electron microscopical level, Neuroscience 22 (1987) 849-862.

[36] S.L. Vincent, Y. Khan, F.M. Benes, Cellular distribution of dopamine D1 and D2 receptors in rat medial prefrontal cortex, J. Neurosci. 13 (1993) 2551-2564.

[37] S.L. Vincent, Y. Khan, F.M. Benes, Cellular colocalization of dopamine D1 and D2 receptors in rat medial prefrontal cortex, Synapse 19 (1995) $112-120$.

[38] Z.X. Wang, B.J. Aragona, Neurochemical regulation of pair bonding in male prairie voles, Physiol. Behav. 83 (2004) 319-328.

[39] Z.X. Wang, Y. Guozhong, C. Cascio, Y. Lui, B. Gingrich, T.R. Insel, Dopamine D2 receptor-mediated regulation of partner preferences in female prairie voles (Microtus ochrogaster): a mechanism for pair bonding? Behav. Neurosci. 113 (1999) 602-611.

[40] Z.X. Wang, T.R. Insel, Parental behavior in voles, Adv. Stud. Behav. 25 (1996) 361-384. 
[41] Z.X. Wang, L.J. Young, Ontogeny of oxytocin and vasopressin receptor binding in the lateral septum in prairie and montane voles, Brain Res. Dev. Brain Res. 104 (1997) 191-195.

[42] Z.X. Wang, L.J. Young, Y. Liu, T.R. Insel, Species differences in vasopressin receptor binding are evident early in development: comparative anatomic studies in prairie and montane voles, J. Comp. Neurol. 378 (1997) 535-546.

[43] J.R. Williams, T.R. Insel, C.R. Harbaugh, C.S. Carter, Oxytocin administered centrally facilitates formation of a partner preference in female prairie voles (Microtus ochrogaster), J. Neuroendocrinol. 6 (1994) 247-250.
[44] J.T. Winslow, N. Hastings, C.S. Carter, C.R. Harbaugh, T.R. Insel, A role for central vasopressin in pair bonding in monogamous prairie voles, Nature 365 (1993) 545-548.

[45] L.J. Young, M.M. Lim, B. Gingrich, T.R. Insel, Cellular mechanisms of social attachment, Horm. Behav. 40 (2001) 133-138.

[46] L.J. Young, Z.X. Wang, The neurobiology of pair bonding, Nat. Neurosci. 7 (2004) 1048-1054.

[47] L.J. Young, J.T. Winslow, R. Nilsen, T.R. Insel, Species differences in V1a receptor gene expression in monogamous and nonmonogamous voles: behavioral consequences, Behav. Neurosci. 111 (1997) 599605 